Original Research Paper

\title{
Increase in Crude Protein Content of Milk Replacers with Vegetable Protein: Effect on Health and Dairy Calves' Performance
}

\author{
${ }^{1}$ Evangelina Miqueo, ${ }^{1}$ Thais Manzoni Torrezan, ${ }^{1}$ Nathalia Britto Rocha, \\ ${ }^{1}$ Marilia Ribeiro De Paula, ${ }^{1}$ Fernanda Lavínia Moura Silva, \\ ${ }^{2}$ Paulo Henrique Mazza Rodrigues and ${ }^{1}$ Carla Maris Machado Bittar \\ ${ }^{1}$ Department of Animal Sciences, University of São Paulo, Av. Padua Dias11, Piracicaba, São Paulo, Brazil \\ ${ }^{2}$ Department of Animal Nutrition and Production, \\ University of São Paulo, Duque de Caxias Norte 225, Pirassununga, São Paulo, Brazil
}

Article history

Received: 15-08-2016

Revised: 06-01-2017

Accepted: 19-01-2017

Corresponding Author:

Carla Maris Machado Bittar

Department of Animal

Sciences, University of São

Paulo, Av. Padua Dias11,

Piracicaba, São Paulo, Brazil

Tel. +55 (19) 3429-4134

Fax: +55 (19) 3429-4215

Email: carlabittar@usp.br

\begin{abstract}
The use of milk replacer instead of whole milk may be an economical alternative to calf-rearing systems. However, together with the volume fed, its composition is critical for high performance, especially regarding the origin of the protein. Two milk replacers with different protein content were evaluated to see the effect on the performance of calves. Thirtythree Holstein calves were distributed in the treatments: (1) High Volume and Low Protein (HV/LP), control group: 8 liters, 19.5\% CP; (2) High volume and high protein (HV/HP): 8 liters, 23.7\% CP and (3) Low Volume and High Protein (LV/HP): 6 liters, $23.7 \%$ CP. Calves were gradually weaned from the seventh week of life. Starter feed intake and fecal score were recorded daily. Weekly, calves were weighed, body measurements taken and blood samples were collected for metabolites analysis. Fecal score was lower $(\mathrm{P}>0.05)$ for animals in treatments HV/LP. Animals in treatments HV/HP had greater number of days in diarrhea $(\mathrm{P}<0.05)$ as compared to LV/HP fed calves. However LV/HP fed calves presented $66.7 \%$ mortality rate with a lower average age at death $(\mathrm{P}<0.05)$. There was no effect of treatments for body weight, average daily gain, body measurements and intake $(\mathrm{P}>0.05)$. Regarding blood metabolites, lactate concentration was higher $(\mathrm{P}<0.05)$ in animals fed $\mathrm{HV} / \mathrm{HP}$ as compared to $\mathrm{LV} / \mathrm{HP}$ and total protein concentration was lower $(\mathrm{P}<0.05)$ for calves fed $\mathrm{HV} / \mathrm{HP}$, while the other metabolic parameters did not differ. The use of substitutes with high vegetable protein content negatively affects the performance of calves and may increase mortality rates when low volumes are fed.
\end{abstract}

Keywords: Calves, Milk Replacer, Feeding, Vegetable Protein

\section{Introduction}

A balanced nutrition is essential for health, welfare and productivity of dairy calves (Conneely et al., 2014). Volume and delivery method of liquid diet, besides influencing immunological, behavioral and economic aspects, also affects body development, mammary gland growth and future milk production. Liquid-feeding management has also a great effect on the starter concentrate intake and thus on the ruminal development (Kertz and Loften, 2013).

During the first weeks of life, calves consume insignificants amounts of solid diet and because of that the nutrients available for growth come almost exclusively from the liquid diet. There are different feeding systems being used for raising dairy calves (Drackley, 2008). The most used is the conventional system, where the calf has a liquid diet supply in a volume of $10 \%$ of Body Weight (BW). The intensive feeding system (over $20 \%$ of calf BW) has been adopted recently because of its positive effects on future milk production, however with problems related to the weaning process. The "Step-down" system, when high volumes fed are gradually reduced days before weaning to stimulate starter concentrate intake has been also adopted as a way to increase nutrients supply via liquid 
feeding without compromise weaning process and subsequent performance.

Recent research established that the effects of feeding calves in future milk production are associated with the kind and amount of nutrients supplied (Moallem et al., 2010). The whole milk, by having the amino acid profile closer to that required by animals for growth, is presented as the most suitable liquid diet option (Davis and Drackley, 1998). However, milk is the main source of income in dairy farms making its supply for animals costly and sometimes impractical. Milk replacer arises as an alternative to whole milk, but sometimes with ingredients not suitable for young dairy calves and inadequate nutrients content.

The high cost of the ingredients, especially milk protein, makes the use of vegetable protein sources an interesting alternative in the formulation of milk replacers. Because the large market availability of soy, its low cost compared to milk protein and favorable profile of amino acids, it is the most interesting alternative, being widely used for that reason (Davis and Drackley, 1998). Using soy protein concentrates and soy isolates have been able to achieve the requirements of calves; however, the use of these ingredients resulted in lower performance in comparison to whole milk, mainly because of inadequate processing and health problems related to allergic process (Lallès, 2000; Drackley et al., 2006). The lower performance of calves fed with some milk replacers may be associated with the presence of anti-nutritional factors such as trypsin inhibitors, antigenic proteins such as glycine and $\beta$-conglycinin, indigestible carbohydrates, lectins, tannins, that are present in some vegetable sources of protein, like soybean (Davis and Drackley, 1998; Chunmei et al., 2010). These factors affect digestion and absorption of protein and carbohydrate digestion, as well as the minerals and vitamins availability. Besides that, during the first three weeks of life, calf's digestive system is poorly adapted to protein sources not derived from milk and this is why in the milk replacer composition the presence of milk protein should predominate (Davis and Drackley, 1998). Thus, the increase in the CP content of milk replacer, to have $\mathrm{CP}$ intake similar to that with whole milk diets, may decrease performance and increase morbidity and mortality of calves.

The aim of this study was to evaluate the effect of two milk replacers with increased protein content, fed in two different volumes, on the performance and metabolism of Holstein calves.

\section{Materials and Methods}

All experimental procedures were approved by the Animal Care and Use Committee of University of São Paulo and were performed in accordance with their guidelines. Thirty three Holstein calves from a commercial farm ( $7 \pm 3$ d of age) were blocked by Body Weight (BW) and date of birth. After birth, calves received $2 \mathrm{~L}$ of high quality colostrum during the first meal and $12 \mathrm{~h}$ latter. Calves were transported to the experimental field at the Agriculture College, University of Sao Paulo and housed in individual hutches with free access to water and starter concentrate (Agroceres Multimix Nutrition Animal Ltda, Rio Claro, SP, Brazil) during the entire experimental period.

Calves were randomly distributed to one of the following treatments, according to volume fed and milk replacer Crude Protein (CP) content: (1) High Volume, Low Protein (HV/LP) control group: $8 \mathrm{~L}, 19.50 \% \mathrm{CP}$; (2) High Volume, High Protein (HV/HP): 8 L, 23.7\% CP and (3) Low Volume, High Protein (HV/HP): 6 L, 23.7\% CP. Milk replacers were diluted for $12.5 \%$ solids and offered in three meals a day $(6,12,18 \mathrm{~h})$. Samples of starter concentrate and milk replacer were collected during the experimental period for subsequent analysis (Table 1).

Animals were weekly weighed in a mechanical scale before the morning feeding, until the 8th week of life. Fecal score was monitored daily as described by Larson et al. (1977) regarding the fluidity of feces, being: (1) normal and firm, (2) loose but with general healthy aspect, (3) very loose not watery separation, (4) watery and (5) very watery. Health problems were monitored and treated according to the veterinary recommendation. All calves presented with diarrhea at least once during the trial and were offered oral electrolytes every time faecal score was higher than 2.5. When fever occurred or tick fever was diagnosed calves were treated with an antibiotic.

Blood samples were collected weekly, always two hours after morning feeding, through jugular vein puncture by vacuolated tubes (Vacuette of Brazil, Campinas, SP, Brazil). Samples were centrifuged (Universal 320R, Hettich, Tuttlinger, German) at 2.000× $g$, for $20 \mathrm{~min}$ at $4^{\circ} \mathrm{C}$ and plasma or serum were stored in a freezer $\left(-26^{\circ} \mathrm{C}\right)$ until subsequent analysis. Specific commercial enzymatic kits from Labtest Diagnóstica S.A. (Lagoa Santa, MG, Brazil) were used to analyzed plasma glucose (ref. 85), total serum protein (ref. 99), serum creatinine (ref. 1010), plasma urea (ref. 104), serum albumin (ref. 19), lactate (ref. 116); and from Randox Laboratories (Life Sciences Ltd., Crumlin, UK) for ß-hydroxybutyrate (BHBA-Ranbut), using the Automatic System for Biochemistry-SBA Model 200 (CELM, Barueri, SP, Brazil). Hematocrit was determined with an aliquot of blood, collected from tube containing anticoagulant, using a microcentrifuge (Microspin, Model Spin 1000 , USA) at $12,000 \times \mathrm{g}$ for $10 \mathrm{~min}$ and then measured in percentage.

Data were analyzed with the Statistical Analysis System (SAS, 1991), according to Proc Mixed, with the collection days as repeated measures. Disease data were also analyzed according to the Proc Mixed, with the 
effects of treatment and covariate initial weight as fixed effects and block as a random effect. Treatments comparison was carried out according to the adjusted Tukey test, with adopted significance level of 5\%. For data without repeated measures, the model used was: Yijk $=\mu+\mathrm{Ti}+\mathrm{PIj}+\mathrm{Bk}+$ eijk where $\mu=$ Overall average; $\mathrm{Ti}=$ fixed effect of treatment; $\mathrm{PIj}=$ initial weight fixed effect (covariate); Bk = random block effect; eijk = random experimental error. The repeated measures were analyzed according to the model: Yijk $=\mu+\mathrm{Ti}+\mathrm{Ij}+\mathrm{TIij}$ $+\mathrm{Bk}+$ eijk where: $\mu=$ overall average; $\mathrm{Ti}=$ Treatment Effect; Ij = effect of age; TIij = interaction Treatment X Age; $\mathrm{Bk}=$ Block effect; eijk = experimental error.

\section{Results}

Calves in treatments with high protein content, regardless of the volume fed, presented higher fecal scores $(\mathrm{P}<0.05$; Table 2$)$. There was an increase in fecal score from the first to the second week of age for all treatments. The combination of Low Volume fed with High Protein (LV/HP) resulted in fewer days with diarrhea $(\mathrm{P}<0.05)$, however these animals presented the higher mortality rate, with an average age at death of 34 days. Regarding hematocrit, there was only effect due to the age of the animals $(\mathrm{P}<0.0001)$, but there were no effects of treatment or interaction treatment $\mathrm{x}$ age $(\mathrm{P}>0.05)$. However, at the end of the trial there was an increase in the hematocrit value for animals on LV/HP treatment. No significant differences were observed related to combination of volume fed and the milk replacer protein

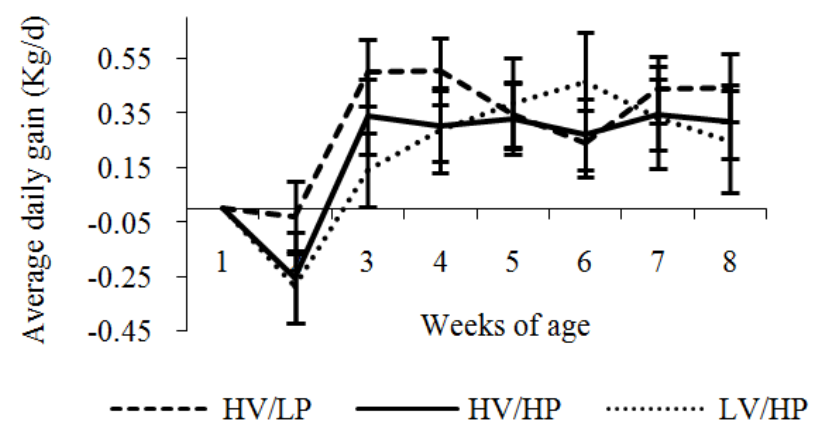

content on the occurrence of other diseases $(\mathrm{P}>0.05$; Table 2). However, two animals on LV/HP treatment lost almost $100 \%$ of the hair, one of them presenting swollen eyes, besides acute diarrhea; while the other calves in this treatment showed mild alopecia.

During the experiment there was a decrease in body weight from week 1 to week $2(\mathrm{P}<0.05$; Table 3; Fig. 1), followed by increases in body weight for all treatments $(\mathrm{P}<0.05)$. A trend may be considered for higher average daily gain for calves fed the low protein milk replacer $(\mathrm{P}=0.08$; Table 3$)$. Starter concentrate intake was also affected by calves age $(\mathrm{P}<0.05)$, with increasing values (Table 3; Fig. 1). Yet, no significant effect were observed for treatments or the interaction between treatment and animals' age $(\mathrm{P}>0.05)$. Calves fed the LV/HP program had the lowest milk replacer intake as planned $(\mathrm{P}<0.05)$, while $\mathrm{HV} / \mathrm{LP}$ and HV/HP presented similar intakes $(\mathrm{P}>0.05)$. Milk replacer intake was affected by animal's age and by the interaction between treatment and age $(\mathrm{P}<0.05)$. Between the first and second week of life, calves consumed less volume than that was supplied. There a high percentage of liquid diet rejection for the high protein milk replacer, independently of the volume fed, explained by the high percentage of animals that needed to be encouraged or helped during the feeding (22 and $26 \%$, respectively for high and low volume fed). In relation to total intake, there were similar responses for all treatments, with effect only of animal's age $(\mathrm{P}<0.0001$; Table 3), with no differences among treatments or interaction treatment $\mathrm{x}$ age $(\mathrm{P}>0.05)$.

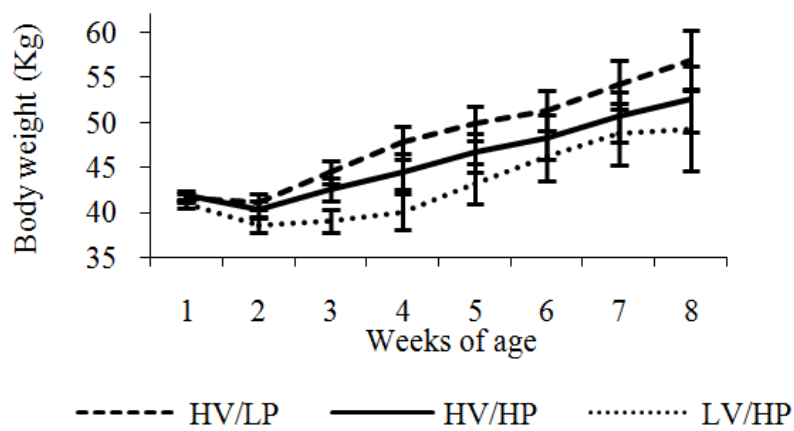

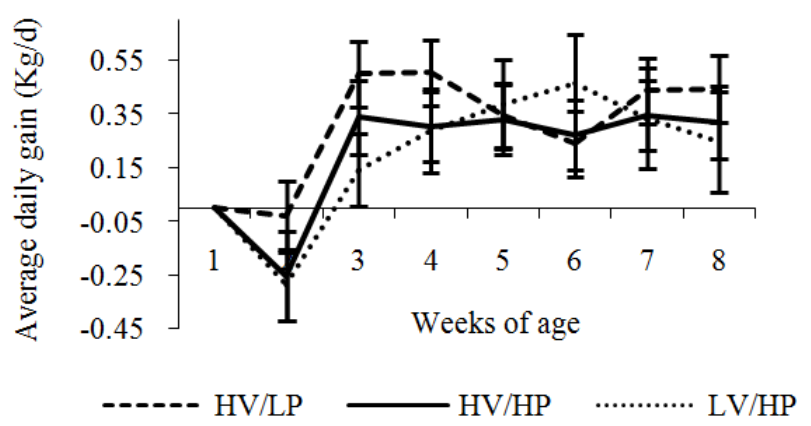

Fig. 1. Starter concentrate intake, body weight and average daily gain of calves fed different volumes of milk replacers with high or low crude protein content 

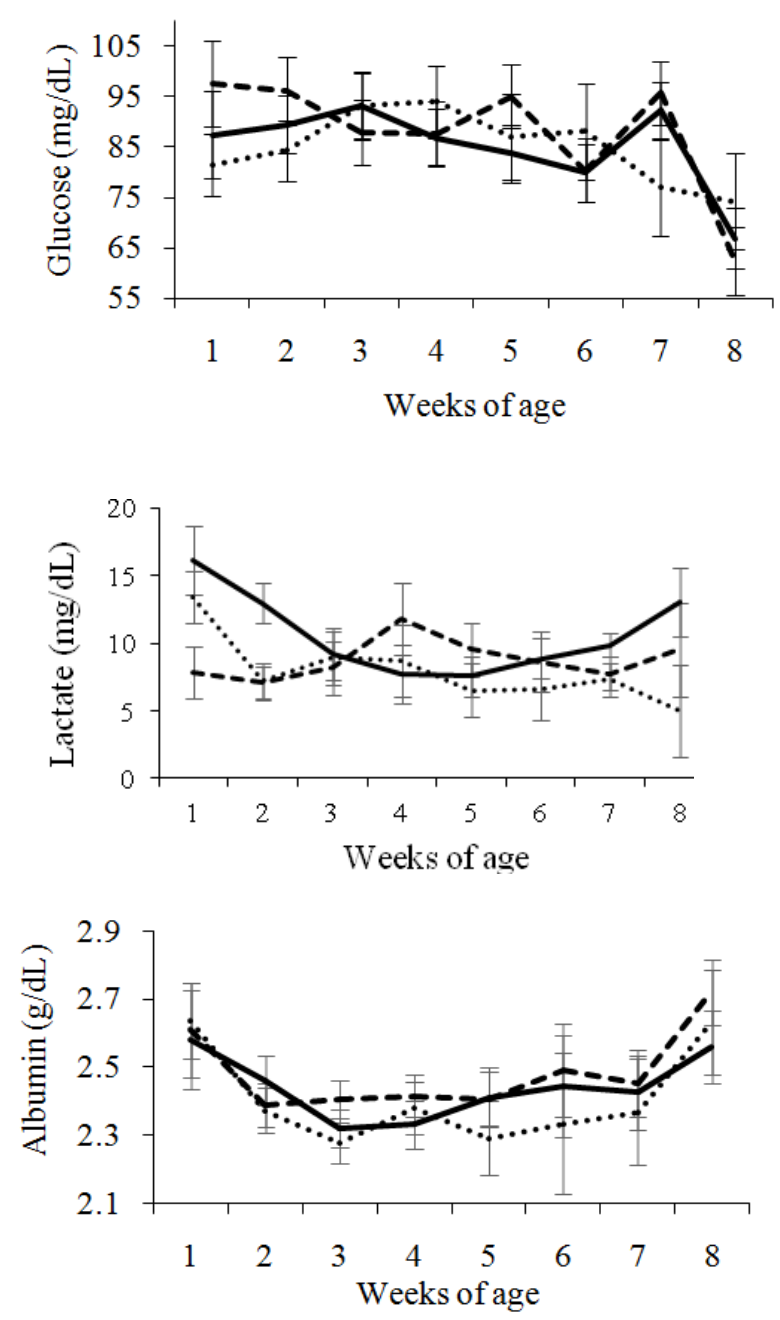
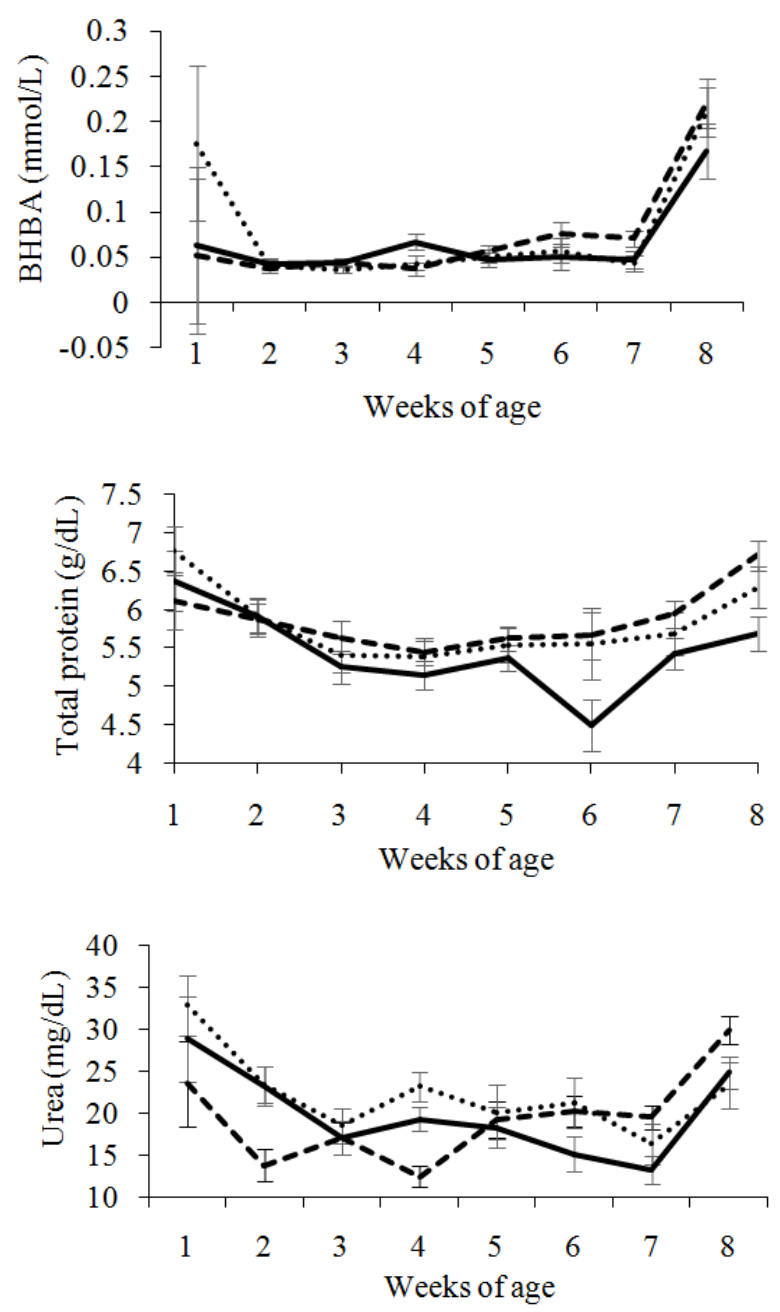

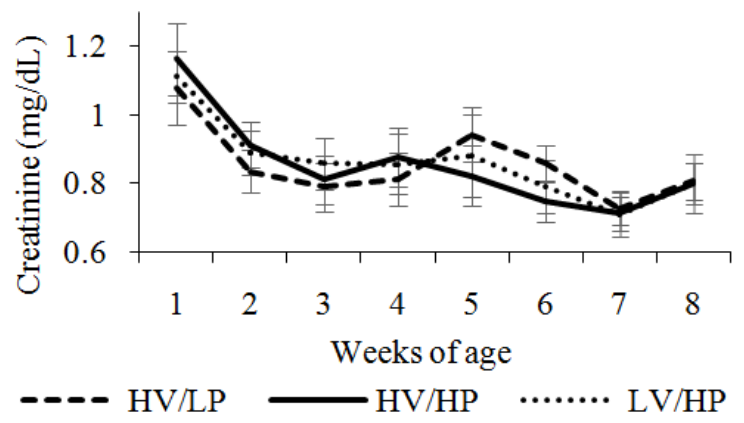

Fig. 2. Glucose, BHBA, lactate, total protein, albumin, urea and creatinine concentration of calves fed different volumes of milk replacers with high or low crude protein content

Regarding metabolic parameters (Table 4; Fig. 2), plasma glucose presented no differences among treatments or interaction between treatment and age $(\mathrm{P}>0.05$; Table 4). However, there was an age effect $(\mathrm{P}<0.05)$, with lower concentration of glucose by the end of the trial. BHBA had an age effect too, but in this case the BHBA concentration increased in the last week of the trial $(\mathrm{P}<0.05$; Table 4). Lactate concentrations in plasma was higher for HV/HP, followed by HV/LP and then by
LV/HP treatment. However, there was no effect of animals' age $(\mathrm{P}>0.05)$ or interaction between treatment and age for lactate concentration $(\mathrm{P}>0.05)$. Total serum protein showed significant differences $(\mathrm{P}<0.05)$ among treatments, with the HV/HP fed calves presenting the lowest level. Albumin, urea and creatinine were not affected by treatments $(\mathrm{P}>0.05)$, but there were an age effect for all of them $(\mathrm{P}<0.0001)$ and an interaction of age and treatment for urea concentration $(\mathrm{P}<0.05)$. 
Table 1. Milk replacer and starter concentrate chemical composition

\begin{tabular}{llll}
\hline & Feeds & & \\
& Low CP Milk Replacer & \\
& - & High CP Milk Replacer & Starter Concentrate $^{\text {b }}$ \\
\hline Dry matter, \% & 96.94 & 96.52 & 90.06 \\
Ash, \% DM & 7.24 & 11.24 & 7.81 \\
Crude protein, \% DM & 19.50 & 23.73 & 23.54 \\
Crude fat, \% DM & 14.37 & 11.64 & 5.24 \\
NDF,\% DM & 0.47 & 0.52 & 15.98 \\
Total digestive nutrients, \% DM & - & - & 84.20 \\
Gross energy, Mcal/kg & $4,557.92$ & $4,501.70$ & - \\
\hline
\end{tabular}

${ }^{\mathrm{c}}$ Starter concentrate, Ag Milk Agroceres Multimix Nutrição Animal Ltda

Table 2. Fecal score, hematocrit, days with diarrhea, age at death, mortality rate and disease occurrence for calves fed different volumes of milk replacers with high or low crude protein content

\begin{tabular}{|c|c|c|c|c|c|c|c|}
\hline & \multicolumn{4}{|c|}{ Treatment $^{1}$} & \multicolumn{3}{|c|}{$\mathrm{P}$ value $^{3}$} \\
\hline & $\mathrm{HV} / \mathrm{LP}$ & $\mathrm{HV} / \mathrm{HP}$ & $\mathrm{LV} / \mathrm{HP}$ & $\mathrm{SEM}^{2}$ & $\mathrm{~T}$ & A & $\mathrm{TxA}$ \\
\hline Fecal score & $2.99^{b}$ & $3.51^{\mathrm{a}}$ & $3.55^{\mathrm{a}}$ & 0.146 & 0.001 & 0.001 & 0.06 \\
\hline Hematocrit, $\%$ & 20.86 & 20.69 & 23.01 & 0.942 & 0.19 & 0.0001 & 0.73 \\
\hline \multirow[t]{2}{*}{ Days with diarrhea } & $37.20^{\mathrm{ab}}$ & $41.10^{\mathrm{a}}$ & $26.20^{b}$ & 2.450 & 0.03 & . & . \\
\hline & \multicolumn{2}{|c|}{ Mortality rate, $\%$} & 0 & 10 & 66.67 & . & . \\
\hline Age at death, days & $\dot{-}$ & $52.10^{\mathrm{a}}$ & $34.10^{\mathrm{b}}$ & 2.760 & 0.001 & . & . \\
\hline Alopecia, $\%$ of total body & 18.2 & 50 & 50 & 8.64 & 0.5094 & . & . \\
\hline Tympanism prevalence, $\%$ & 45.5 & 10 & 16.7 & 7.6 & 0.1467 & . & . \\
\hline Pneumonia prevalence, $\%$ & 18.2 & 20 & 8.3 & 6.3 & 0.6303 & . & . \\
\hline Tick Fever prevalence, $\%$ & 36.4 & 80 & 16.7 & 8.7 & 0.3415 & . & . \\
\hline Joints prevalence, $\%$ & 18.2 & 0 & 0 & 4.22 & 0.1269 & . & . \\
\hline Others, $\%$ & 0 & 10 & 8.3 & 4.22 & 0.5892 & . & . \\
\hline
\end{tabular}

${ }^{\mathrm{T}} \mathrm{HV} / \mathrm{LP}$ : high volume/low protein; HV/HP: High volume/high protein; LV/HP: Low volume/high protein

${ }^{2}$ SEM: Standard error of the mean

${ }^{3}$ T: Treatment effect, A: Age effect, TxA: Interaction Treatment x age

Table 3. Body weight, average daily gain, starter intake, milk replacer intake and total for calves fed different volumes of milk replacers with high or low crude protein content

\begin{tabular}{|c|c|c|c|c|c|c|c|}
\hline & \multicolumn{3}{|c|}{ Treatment $^{1}$} & \multirow[b]{2}{*}{$\mathrm{SEM}^{2}$} & \multicolumn{3}{|c|}{$\mathrm{P}$ value ${ }^{3}$} \\
\hline & $\mathrm{HV} / \mathrm{LP}$ & $\mathrm{HV} / \mathrm{HP}$ & $\mathrm{LV} / \mathrm{HP}$ & & $\mathrm{T}$ & A & TxA \\
\hline \multicolumn{8}{|l|}{ Body weight, $\mathrm{Kg}$} \\
\hline Initial & 38.62 & 39.62 & 38.79 & 1.507 & 0.4 & . & . \\
\hline Weaning & 57.93 & 55.34 & 57.23 & 4.227 & 0.73 & . & \\
\hline Average total period & 48.39 & 45.91 & 43.23 & 1.810 & 0.15 & $<.0001$ & 0.62 \\
\hline $\begin{array}{l}\text { Average daily gain, } \mathrm{kg} \\
\text { Intake, g MS/d }\end{array}$ & 0.35 & 0.24 & 0.23 & 0.08 & 0.21 & $<.0001$ & 0.89 \\
\hline Starter intake & 236.51 & 192.98 & 280.12 & 38.54 & 0.33 & $<.0001$ & 0.96 \\
\hline Milk replacer intake & $771.0^{\mathrm{a}}$ & $728.6^{\mathrm{a}}$ & $602.0^{\mathrm{b}}$ & 24.70 & $<0.01$ & $<.0001$ & $<.01$ \\
\hline Total intake & 1010.79 & 910.75 & 981.62 & 44.34 & 0.18 & $<.0001$ & 0.12 \\
\hline
\end{tabular}

${ }^{\mathrm{T}} \mathrm{HV} / \mathrm{LP}$ : High volume/low protein; HV/HP: High volume/high protein; LV/HP: Low volume/high protein

${ }^{2}$ SEM: Standard error of the mean

${ }^{3}$ T: Treatment effect, A: Age effect, TxA: Interaction Treatment x age

Table 4. Blood metabolites of calves fed different volumes of milk replacers with high or low crude protein content

\begin{tabular}{llllllll}
\hline & \multicolumn{3}{l}{ Treatment $^{1}$} & & \multicolumn{3}{c}{ P value $^{3}$} \\
& HV/LP & HV/HP & LV/HP & SEM $^{2}$ & T & A & TxA \\
\hline Glucose, $\mathrm{mg} / \mathrm{dL}$ & 84.88 & 87.77 & 84.83 & 2.660 & 0.63 & 0.003 \\
BHBA, $\mathrm{mmol} / \mathrm{L}$ & 0.07 & 0.06 & 0.08 & 0.012 & 0.60 & $<.0001$ & 0.71 \\
Lactate, $\mathrm{mg} / \mathrm{dL}$ & $8.79^{\mathrm{ab}}$ & $10.68^{\mathrm{a}}$ & $7.97^{\mathrm{b}}$ & 0.698 & 0.03 & 0.22 & 0.19 \\
Total protein, g/dL & $5.88^{\mathrm{a}}$ & $5.46^{\mathrm{b}}$ & $5.82^{\mathrm{a}}$ & 0.150 & 0.04 & $<.0001$ & 0.37 \\
Albumin, g/dL & 2.49 & 2.44 & 2.41 & 0.069 & 0.71 & $<.0001$ & 0.62 \\
Urea, mg/dL & 19.46 & 19.975 & 22.37 & 1.077 & 0.15 & $<.0001$ & 0.0002 \\
Creatinine, $\mathrm{mg} / \mathrm{dL}$ & 0.86 & 0.85 & 0.86 & 0.044 & 0.98 & $<.0001$ & 0.99 \\
\hline
\end{tabular}

${ }^{\mathrm{T}} \mathrm{HV} / \mathrm{LP}$ : High volume/low protein; HV/HP: High volume/high protein; LV/HP: Low volume/high protein

${ }^{2}$ SEM: Standard error of the mean

${ }^{3}$ T: Treatment effect, A: Age effect, TxA: Interaction Treatment $\mathrm{x}$ age 


\section{Discussion}

The low CP milk replacer (Table 1) contained crude protein and crude fat values within the range of that recommended by NRC (2001). The NDF content was $0.47 \%$ DM, very close to the value that Davis and Drackley (1998) published as indicative of the presence of vegetable protein in the formula $(0.5 \%)$, therefore it is believed that this milk replacer contained vegetable protein. Protein content and crude fat were also within the values recommended by the NRC (2001) for the high CP content milk replacer, even though fat was very low as compared to that observed in milk. The NDF exceeds $0.5 \%$ suggesting that this milk replacer has a large proportion of vegetable protein. The lack of adequate processing of soy products or its excessive inclusion in the milk replacer formulation can adversely affect the calves' health, producing disorders like indigestion, malabsorption, abnormal intestinal motility and diarrhea (Lallès, 1993).

The higher fecal score in those calves fed the high CP milk replacer could be related with the type of protein included in its composition. Moreover, there was also an age effect, which is associated with increased risk of diarrhea between the seventh and tenth day of life (Buenau et al., 2005). These results are similar to those reported by Gardner et al. (1990), who associated high fecal scores to the higher abomasum $\mathrm{pH}$, as compared to animals consuming whole milk, the absence of clot formation and rapid passage of this liquid diet to the duodenum. A large proportion of animals on LV/HP treatment were affected by severe diarrhea and died before the end of the trial period (66.67\%). Accordingly, Gardner et al. (1990) reported high mortality rates of calves receiving milk replacer with soy protein and these deaths were usually preceded by severe diarrhea. These authors also reported accumulation of gas in the rumen and abomasum in some of the experimental animals and this feature was observed postmortem on LV/HP fed calves. Lallès et al. (1995) also report death of two animals consuming milk replacer with soy protein by swelling and dehydration between the sixth and tenth week of life. The increase on hematocrit in the last period of experiment could indicate dehydration due to diarrhea. It was expected that animals fed HV/HP presented a similar behavior because of high fecal score presented during this period. One possible explanation could be the greatest volume of liquid diet consumed by animals on HV/LP and HV/HP treatments, which would decrease dehydration. Regarding other diseases, alopecia and swollen eyes presented in some calves after diarrhea could indicate feed's adverse response and malnutrition. Other diseases occurred during the trial, however none of them were statistically related to the milk replacer CP level or volume fed (Table 2).
There was a poor animal performance during the eight weeks of experiment, which could be associated with the milk replacer composition, since calves have no enzyme apparatus fully developed at this time for digestion of vegetable protein. França et al. (2011) reported similar results related to body weight, with no differences between treatments and no interaction between treatment and age. The weight loss during the first weeks of age was expected due to high incidence of diarrhea observed during this period because of animals immunity fall. In addition, during the first weeks of the calf's life, due to insufficient development of the enzymatic apparatus, there is a low utilization of the nutrients contained in this type of milk replacer thus affecting the animal performance (Davis and Drackley, 1998). The presence of trypsin inhibiting factors and changes in the intestinal flow could have influenced animal's weight (Drackley et al., 2006). The absence of effect in ADG agrees with similar results obtained by Ghorbani et al. (2007). In these type of milk replacers, daily gain is mostly affected by the liquid diet composition, not by the volume fed; therefore, there is no compensatory effect to justify an increase on milk replacer feeding (6 vs $8 \mathrm{~L} / \mathrm{d}$ ) when low quality $\mathrm{CP}$ is included. Furthermore, ADG (Table 3) is below values that the literature recognizes as ideal to reach puberty and first calving at adequate ages, which would be around 800-900 g/d (Lammers et al., 1998).

Animals fed lower volumes of milk replacer presented numerically higher starter intake in an attempt to cover the nutritional needs (Fig. 1); however, no statistical differences were detected, because all calves present the same behavior increasing their intake. Although this consumption was not different as compared to the other treatments $(\mathrm{P}>0.05)$, it compensated the lower milk replacer intake by LV/HP calves, resulting in similar total intake among treatments (Table 3). The increase in solid diet intake from the seventh week of life occurred as a response to the decrease on milk replacer supply, as part of the gradual weaning process (Fig. 1). The highest starter intake of calves in LV/HP treatment may be related to lower intake of liquid diet, which favored to a higher starter intake at the final stage of the trial, as explained above.

Blood metabolites reflected treatments effects on starter intake (Fig. 2). Glucose concentration decreased with age as a response of the lower milk volume fed during the last week and consequent increased concentrate intake, being the levels of this metabolite similar to those reported by Shingu et al. (2007). BHBA concentrations were also only affected by age, which was expected since as the rumen develops and begin to produce short chain fatty acids, rumen epithelium metabolize butyrate to BHBA. Together with acetate, BHBA will gradually become the main sources of energy as glucose availability decreases. The concentration of 
BHBA in this study had an opposite behavior to the concentration of glucose, as expected, showing a marked increase in the last week of life related to gradual weaning and consequent increase in concentrate intake. Nevertheless, it was expected that BHBA content of animals in LV/HP treatment were higher compared to the other treatments, because of the also expected increased concentrate intake in to the lower volume of liquid diet consumed, as published by Kristensen et al. (2007). The high lactate concentration over the experiment could be related with the high amount of non-fibrous carbohydrates, which have a rapid degradation enabling rapid availability of nutrients for the rumen bacteria thus producing lactate (Kozloski, 2011), from which the liver only captures a small proportion remaining in circulation a significant amount of this metabolite.

The total serum protein concentration is below those mentioned in the literature (6-8.5 $\left.\mathrm{g} \mathrm{dL}^{-1}\right)$ as a reference for Holstein breed animals (Luca and Reis, 2001). Values above or below those are indicators of a feeding or metabolic disorder. Calves had the serum protein value within the range known as normal for calves at that age until the second week of age. However, from the second week to the seventh week of life (Fig. 2), the concentration decreased and remained below the lower reference limit. Probably the smaller protein values relative to those in the literature are the consequence of poor milk replacer quality fed as regard to its limited digestibility of protein used in the formulation. Leal et al. (2003) observed similar protein concentrations for calves during the first week of life $\left(6.95 \mathrm{~g} \mathrm{dL}^{-1}\right)$; however, values reported for 30 days of life were higher than those obtained in the present study. Feitosa et al. (2001) reported protein concentrations of $5.96 \mathrm{~g} \mathrm{dL}^{-1}$ at 30 days of life, similar to what was observed as an average in the present study (Table 4). Variations in albumins' concentrations according to age were not expected since this metabolite tends to be constant over time (Leal et al., 2003). However, Feitosa et al. (2001) reported constant and gradual increases in albumin concentration starting from $2.63 \mathrm{~g} \mathrm{dL}^{-1}$ at birth and reaching a maximum value of $3.57 \mathrm{~g} \mathrm{dL}^{-1}$ at 180 days old. Serum urea concentration is a parameter that can be used for determining the kidneys function; however, this metabolite is subject to variation due to feed, tissue degradation, gastrointestinal bleeding, liver disease, among others (Traynor et al., 2006). The average plasma urea concentration was not affected by treatments $(\mathrm{P}>0.05)$, in accordance with data published by Khorasani et al. (1989). Nitsan et al. (1971) reported similar values of plasma urea to animals fed whole milk and that receiving milk replacer containing soybean. Hayashi et al. (2006) obtained plasma urea concentration values in the fourth week after calves' birth of approximately $24 \mathrm{mg} \mathrm{dL}{ }^{-1}$, which coincides partly with the values obtained in the current study for treating LV/HP and $\mathrm{HV} / \mathrm{HP}$. Because this parameter is strongly influenced by the diet consumed, the behavior of the curve HV/LP treatment could be explained by the milk replacer lower protein content. The measurement of blood creatinine concentration is a good indicator of kidney function with increases in concentration when there is a dysfunction (Traynor et al., 2006). Benesi et al. (2005) identified as normal for one-week-old calves creatinine values of 1.51 to $1.38 \mathrm{mg} \mathrm{dL}^{-1}$; for animals 3 weeks old of 1.32 to $1.30 \mathrm{mg} \mathrm{dL}^{-1}$; and for animals with six weeks old of $1.28 \mathrm{mg} \mathrm{dL}^{-1}$. The values obtained in this study were lower for the three treatments as compared to those cited by these authors. Nevertheless, this metabolite decreased as animals aged, coinciding with the trend of the data mentioned above.

\section{Conclusion}

The use of milk replacer with $24 \%$ protein did not improve the performance of dairy calves, independently of volume fed, due to the inclusion of vegetable protein and its effect increasing diarrhea occurrence. In addition, calves fed low volumes of the high protein milk replacer presented high mortality rates.

\section{Acknowledgement}

The authors would like to acknowledge the continued support received from College of Agriculture "Luiz de Queiroz". The authors also appreciate the technical help provided by the co-workers.

\section{Funding Information}

The authors wish to express their appreciation for the financial support provided by the Sao Paulo Research Foundation (Fapesp) and by the Coordination for the Improvement of Higher Education Personnel (CAPES) as a scholarship.

\section{Author's Contributions}

Evangelina Miqueo: Study conception and design, conduction of the experiment, contribution to data interpretation and writing of the manuscript.

Thais Manzoni Torrezan, Nathalia Britto Rocha, Marilia Ribeiro De Paula and Fernanda Lavínia Moura Silva: Study conception and design and conduction of the experiment.

Paulo Henrique Mazza Rodrigues: Conducted statistical analysis and contributed to data interpretation.

Carla Maris Machado Bittar: Contributed to the conception and design of the study, data interpretation and writing of the manuscript, critical revision of the manuscript and final approval. 


\section{Ethics}

This article is original and contains unpublished material. The corresponding author confirms that all of the other authors have read and approved the manuscript and no ethical issues involved.

\section{Disclosure Statement}

The authors warrant that there are no conflicts of interests among authors and between authors and other people, institutions or organizations.

\section{References}

Benesi, F.J., C.S. Coelho, M.L.R. Leal, R.M.S. Mirandola and J.A.N. Lisbôa, 2005. Severity and nature of acidosis in diarrheic calves over and under one week of age. Braz. J. Vet. Res. Anim. Sci., 42: 291-298.

Buenau, R., L. Jaekel, E. Schubotz, S. Schwarz and T. Stroff et al., 2005. Escherichia coli Strain Nissle 1917: Significant reduction of neonatal calf diarrhea. J. Dairy Sci., 88: 317-323. DOI: $10.3168 /$ jds.S0022-0302(05)72690-4

Chunmei, G., P. Hongbin, S. Zewei and Q. Guixin, 2010. Effect of soybean variety on anti-nutritional factors content and growth performance and nutrients metabolism in rat. Int. J. Mol. Sci., 11: 1048-1056. DOI: $10.3390 /$ ijms 11031048

Conneely, M., D.P. Berry, J.P. Murphy, I. Lorenz and M.L. Doherty et al., 2014. Effects of milk feeding volume and frequency on body weight and health of dairy heifer calves. Livest. Sci., 161: 90-94. DOI: 10.1016/j.livsci.2013.12.022

Davis, C.L. and J.K. Drackley, 1998. The Development, Nutrition and Management of the Young Calf. 1st Edn., Iowa State University Press, Ames, ISBN-10: 0813829801, pp: 339.

Drackley, J.K., R.M. Blome, K.S. Bartlett and K.L. Bailey, 2006. Supplementation of $1 \%$ L-glutamine to milk replacer does not overcome the growth depression in calves caused by soy protein concentrate. J. Dairy Sci., 89: 1688-1693. DOI: $10.3168 /$ jds.S0022-0302(06)72236-6

Drackley, J.K., 2008. Calf nutrition from birth to breeding. Vet. Clin. North Am., 24: 55-86. DOI: $10.1016 /$ j.cvfa.2008.01.001

Feitosa, F.L.F., E.H. Birgel, R.M.S. Mirandola and S.H.V. Perri, 2001. Proteinograma sérico de bezerros holandeses do nascimento até um ano de vida. Rev. Bras. Cienc. Vet., 8: 105-108. DOI: $10.4322 /$ rbcv.2015.224

França, S.R.A., S.G. Coelho, A.U. Carvalho, R.G.R. Martins and S.L.M. Ribeiro, 2011. Desempenho de bezerros alimentados usando de sucedâneo até 56 dias de idade. Rev. Ceres., 58: 790-793. DOI: $10.1590 / \mathrm{S} 0034-737 X 2011000600016$
Gardner, R.W., M.G. Shupe, W. Brimhall and D.J. Weber, 1990. Causes of adverse responses to soybean milk replacers in young calves. J. Dairy Sci., 73: 1312-1317. DOI: $10.3168 /$ jds.S0022-0302(90)78797-8

Ghorbani, G.R., R. Kowsar, M. Alikhani and A. Nikkhah, 2007. Soymilk as a novel milk replacer to stimulate early calf starter intake and reduce weaning age and costs. J. Dairy Sci., 90: 5692-5697.

DOI: $10.3168 /$ JDS.2007-0431

Hayashi, H., M. Kawai, I. Nonaka, F. Terada and K. Katoh et al., 2006. Developmental changes in the kinetics of glucose and urea in Holstein calves. J. Dairy Sci., 89: 1654-1661. DOI: $10.3168 /$ jds.S0022-0302(06)72232-9

Kertz, A.F. and J.R. Loften, 2013. Review: A historical perspective of specific milk-replacer feeding programs in the United States and effects on eventual performance of Holstein dairy calves. PAS, 29: 321-332. DOI: 10.15232/S1080-7446(15)30245-X

Khorasani, G.R., W.C. Sauer, F. Maenhout and J.J. Kennelly, 1989. Substitution of milk protein with soyflour or meat-solubles n calf milk replacers. Can. J. Anim. Sci., 69: 373-382. DOI: 10.4141/cjas89-042

Kozloski, G.V., 2011. Bioquímica Dos Ruminantes. 3 Edn., da UFSM, Santa Maria.

Kristensen, N.B., J. Sehested, S.K. Jensen and M. Vestergaard, 2007. Effect of milk allowance on concentrate intake, ruminal environment and ruminal development in milk-fed holstein calves. J. Dairy Sci., 90: 4346-4355. DOI: $10.3168 /$ jds.2006-885

Lallès, J.P., 2000. Soy Products as Protein Sources for Preruminants and Young Pigs. In: Soy in Animal Nutrition. Drackley, J.K. (Ed.), Federation of Animal Science Societies, Savoy, ISBN-10: 1884706010 , pp: 106-126.

Lallès, J.P., 1993. Nutritional and antinutritional aspects of soyabean and field pea proteins used in veal calf production: A review. Livest. Prod Sci., 34: 181-202. DOI: 10.1016/0301-6226(93)90106-R

Lallès, J.P., D. Dréau, A. Huet and R. Toullec, 1995. Systemic and local gut-specific antibody responses in preruminant Calves sensitive to soya. Res. Vet. Sci., 59: 56-60. DOI: 10.1016/0034-5288(95)90031-4

Lammers, B.P., A.J. Heinrichs and A. Aydin, 1998. The effect of whey protein concentrate or dried skim milk in milk replacer on calf performance and blood metabolites. J. Dairy Sci., 81: 1940-1945. DOI: $10.3168 /$ jds.S0022-0302(98)75767-4

Larson, L.L., F.G. Owen, J.L. Albright, R.D. Appleman and R.C. Lamb et al., 1977. Guidelines toward more uniformity in measuring and reporting calf experimental data. J. Dairy Sci., 60: 989-991. DOI: $10.3168 / j d s . S 0022-0302(77) 83975-1$ 
Leal, M.L.R., F.C. Cyrillo, C.S. Mori, L.E.S. Michima and M. Nichi et al., 2008. Modelo de indução de diarréia osmótica em bezerros holandeses. Ciênc Rural., 38: 1650-1657. DOI: $10.1590 / \mathrm{S} 0103-84782008000600024$

Luca, G.C. and B.F. Reis, 2001. Espectrofotometria de proteínas totais em plasma de sangue bovino por análise em fluxo. Sci. Agric., 59: 251-256.

DOI: $10.1590 / \mathrm{S} 0103-90162002000200007$

Moallem, U., D. Werner, H. Lehrer, M. Zachut and L. Livshitz et al., 2010. Long-term effects of ad libitum whole milk prior to weaning and prepubertal protein supplementation on skeletal growth rate and first-lactation milk production. J. Dairy Sci., 93: 2639-2650.

DOI: $10.3168 /$ jds.2009-3007

NRC, 2001. Nutrients Requirements of Dairy Cattle, 7th Edn. National Academy of Sciences, Washington.
Nitsan, Z., R. Volcani, S. Gordin and A. Hasdai, 1971. Growth and nutrient utilization by calves fed milk replacers containing milk or soybean proteinconcentrate heated to various degrees. J. Dairy Sci., 54: 1294-1299.

DOI: 10.3168/JDS.S0022-0302(71)86023-X

SAS, 1991. SAS/STAT® user's guide, version 9.2. SAS Institute Inc., Cary, NC.

Shingu, H., H. Hayashi, E. Touno, A. Oshibe and S. Kushibiki et al., 2007. Characteristics of developmental changes in the kinetics of glucose and urea in Japanese Black calves: Comparison with Holstein calves. J. Dairy Sci., 85: 2910-2915. DOI: $10.2527 /$ jas.2007-0100

Traynor, J., R. Mactier, C.C. Geddes and J.G. Fox, 2006. How to measure renal function in clinical practice. Br. Med. J., 333: 733-737. DOI: $10.1136 / \mathrm{bmj} .38975 .390370 .7 \mathrm{C}$ 